\title{
PICHAÇÃO: UMA VOZ URBANA
}

Rebeca Soares de Lima ${ }^{1}$ Maison Antonio dos Anjos Batista ${ }^{2}$

RESUMO: Deixar uma marca em um muro, desenhar um símbolo, subir em prédios, arriscando a própria vida. Esta é a atividade que muitos pichadores se orgulham de realizar. Orgulham-se, mas poucos sabem exatamente quem é o autor de determinada inscrição ou símbolo. Diante de um ato que beira uma necessidade de ser visto e ouvido por uma sociedade que o ignora, este artigo se propõe a analisar frases legíveis, pichadas nas avenidas Constantino Nery e Djalma Batista, na zona comercial da cidade de Manaus, identificando as manifestações de autoria; e também se as manifestações escritas podem ser classificadas como práticas de um espaço urbano específico, como de Manaus. Ao fim, percebeu-se que as manifestações escritas puderam relevar necessidade de demarcar território, expor protestos sociais e confirmar a atividade como legítima, expondo-se como sujeitos críticos e cientes do espaço que ocupam.

PALAVRAS-CHAVE: Pichação, muro, urbano.

ABSTRACT: Leave a mark on a wall, draw a symbol, climbing buildings, risking his own life. This is the activity that many taggers are proud to accomplish. They pride themselves, but few know exactly who is the author of a particular description or symbol. Faced with an act that borders a need to be seen and heard by a society that ignores, this article aims to analyze readable phrases painted on avenues Constantino Nery and Djalma Batista, in the commercial area of the city of Manaus, also identifying the manifestations authorship ; and identify also the written statements can be classified as practices of a specific urban space, such as Manaus. In the end, it was noticed that the written statements could reveal the need to demarcate territory, exposing social protest and confirm the activity as legitimate, exposing themselves as critical and aware subjects of space they occupy.

KEY WORDS: Graffiti, wall , urban.

\section{CONSIDERAÇÕES INICIAIS}

Escrever em paredes não é, em si, algo que se possa dizer novo. Desde a antiguidade, percebe-se escritos e desenhos nas paredes de cavernas e nas de palácios egípcios, por exemplo. Contudo, essas inscrições em paredes não eram categorizadas como transgressão, pelo contrário, eram autorizadas, eram legitimadas, e, muitas vezes, não era um exercício de baixo custo.

\footnotetext{
1 Mestre em Literatura pela Universidade do Estado do Amazonas. Professor da SEDUC-AM (Secretaria de Educação) E-mail: rebbeccalima@ hotmail.com

2 Mestrando em Literatura pela Universidade do Estado do Amazonas. Professor da SEDUC-AM (Secretaria de Educação) E-mail: Maisondosanjos3@yahoo.com.br
} 
Contemporaneamente, a própria ideia de “outdoor” resume-se a símbolos e frases curtas para leitura rápida, com a finalidade de divulgar ideias e/ou produtos. Na maioria dos casos, a leitura deste é realizada sem que a própria pessoa o pense em fazer, mas o faz pelo simples comportamento impulsivo, de saber ler ou geralmente por ter um arranjo de cores que atraia a atenção. Ora, para Farias, "toda e qualquer cidade encontra-se suscetível a transformar-se, em virtude da ação daqueles que a conceberam ou que dela se apropriaram”. (FARIAS, 2010, p. 55)

Muitas vezes, assim acontecem com as pichações, elas fazem parte da cidade e a transforma, modificando-a. Quem o faz procura o lugar que possua uma grande visibilidade e que seja passagem de muitas pessoas, por mais que seja de difícil acesso. Duarte (2009, p. 9), relata que "as pichações sublinham a cenografia urbana do suporte acessível e de risco, com dificuldades de acesso, vigilância, agregando traços de um jogo de risco-limite ao próprio ato da escrita".

Diante disso, umas das características das pichações é a ilegalidade, o perigo que isso envolve, já que os espaços não são comprados e/ou autorizados para tal, além desse estilo de exposição não ser também reconhecido como uma forma de arte. "A pichação precisa da marginalização decorrente da sua ilegalidade e do seu caráter invasivo”. (TAVARES, 2009, p. 24)

Mesmo com a proibição do estado, e porque não dizer dos que fazem parte dele, os cidadãos, a pichação está aos olhos de qualquer um, e sua extinção é de difícil execução. Se mesmo com leis e punições legitimadas e em vigor, porque os que as praticam continuam a se multiplicar? O que move pessoas a destinar tempo, principalmente as da madrugada, para deixar uma marca, um protesto? Que desejo é esse de deixar uma marca, de forma transgressora?

Perante tantos questionamentos, pode-se supor então, que o simples ato de transgredir e deixar algo inscrito revela tanto quanto seu conteúdo, pois o lugar escolhido e sua visibilidade são significativos. Ou seja, "os atos de pichação podem ser ferramentas para investigar sentidos, representações e memórias do espaço". (MARQUES, 2015, p. 80)

Podemos diante disso, refletir tanto sobre quem deixa uma marca, uma assinatura, uma frase no muro quanto o lugar onde o esse está situado, quem por ali passa, o que se pode objetivar com o espaço físico que rodeia esta inscrição. Diante disso, estamos frente a uma das definições da cidade. Lewis Mumford citado por Farias (2010, p. 33), afirma "que as cidades nascem das necessidades sociais do indivíduo, o qual encontra um meio propício para a difusão de seus costumes e ampliação do diálogo com o outro." 
Ora, as pichações podem ser percebidas como uma forma de comunicação. A maioria delas é direcionada a alguém ou um grupo, pois possui um emissor, um receptor (o outro), o veículo e a mensagem, feita a partir de um código; terminando geralmente com uma saudação e uma assinatura, ou o que é chamado de tags - uma marca que caracteriza alguém especificamente ou um grupo que partilha de um mesmo ideal ou que "possui”" ou domina um lugar, uma rua, um muro. Marques (2015, p. 87) expõe que "é necessário estender o olhar, compreender uma pichação para além do seu conceito criminal, percebendo nela uma forma de territorialização na cidade."

Assim posto, este artigo visa analisar frases legíveis, pichadas nas avenidas Constantino Nery e Djalma Batista, na zona comercial da cidade de Manaus, identificando também as manifestações de autoria; e se as manifestações escritas podem ser classificadas como práticas de um espaço urbano específico, como de Manaus.

\section{EU EXISTO!}

Um dos primeiros fatores percebidos com o ato de fotografar pichações, ao longo de duas avenidas muito movimentadas da cidade, é a necessidade de delimitar, marcar um território, de dominar ou quase possuir uma área. Entretanto, outros também o desejam fazer, gerando rivalidades perceptíveis. Estas inscrições de território deixam a cidade com "uma estética outra que faz da cidade um imenso caderno... indecifrável para uns e legível para outros... uma cidade que berra!”. (MARIANI, 2014, p. 135)

Berra, grita: eu existo! Uma voz marginalizada, uma voz que parece não encontrar vez nem lugar na cidade. É interessante essa contradição, pois na mesma proporção que o desejo de ser visto se faz, as inscrições precisam ser feitas as escondidas, em horário em que há pouco ou nenhum movimento, para que não haja punição pela inscrição realizada, já que essa é considerada ilegal. Para Tavares (2009, p.24), “a estratégia dos pichadores parece ter uma motivação, como um contra-ataque às políticas do uso do espaço urbano. O território, até onde a vista alcança, não lhes pertence.” 


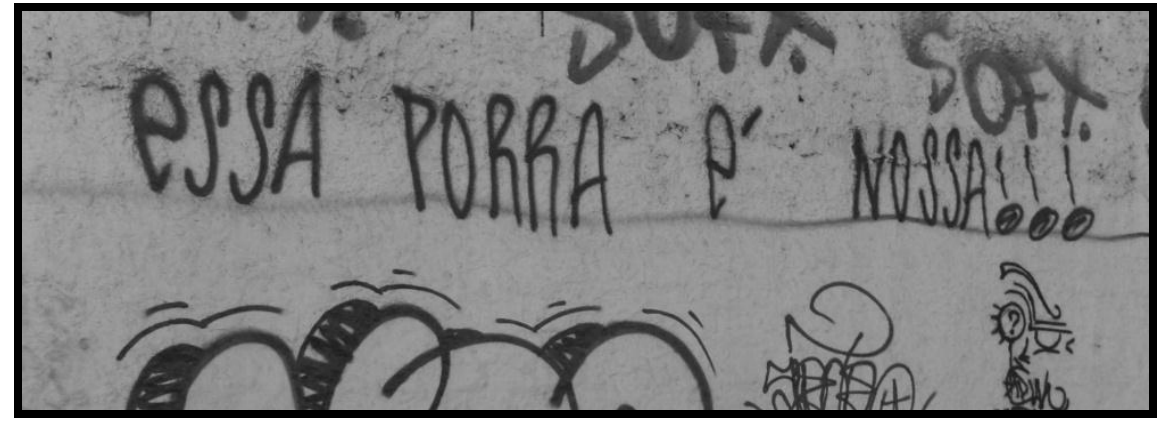

Figura 1: Muro da empresa Andrade Gutierrez, na Av. Constantino Ney em frente à Arena da Amazônia

(foto de Rebeca Soares e Maison dos Anjos em 21 de abril de 2015)

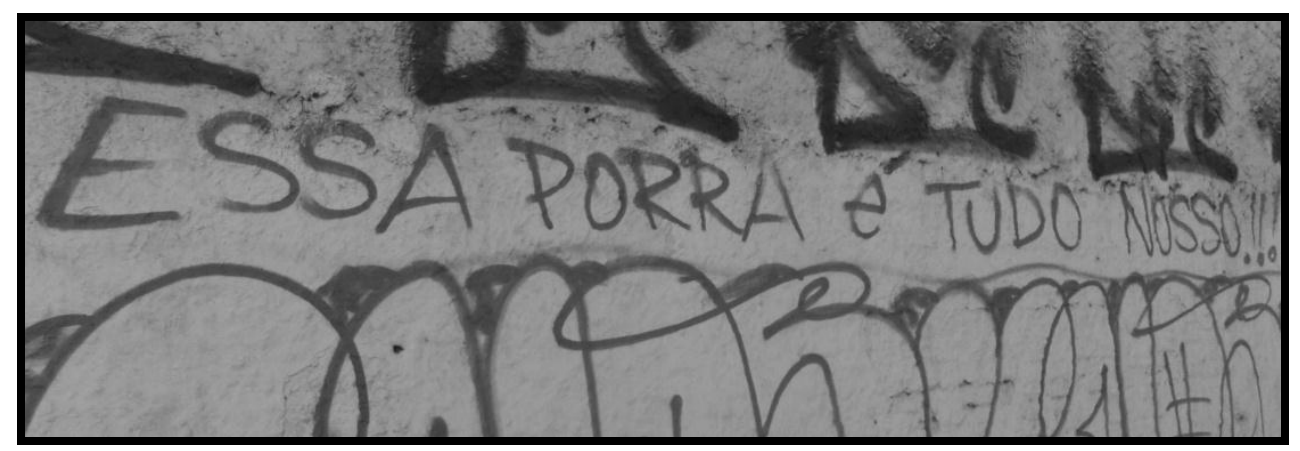

Figura 2: Muro da empresa Andrade Gutierrez, na Av. Constantino Ney em frente à Arena da Amazônia

(foto de Rebeca Soares e Maison dos Anjos em 21 de abril de 2015)

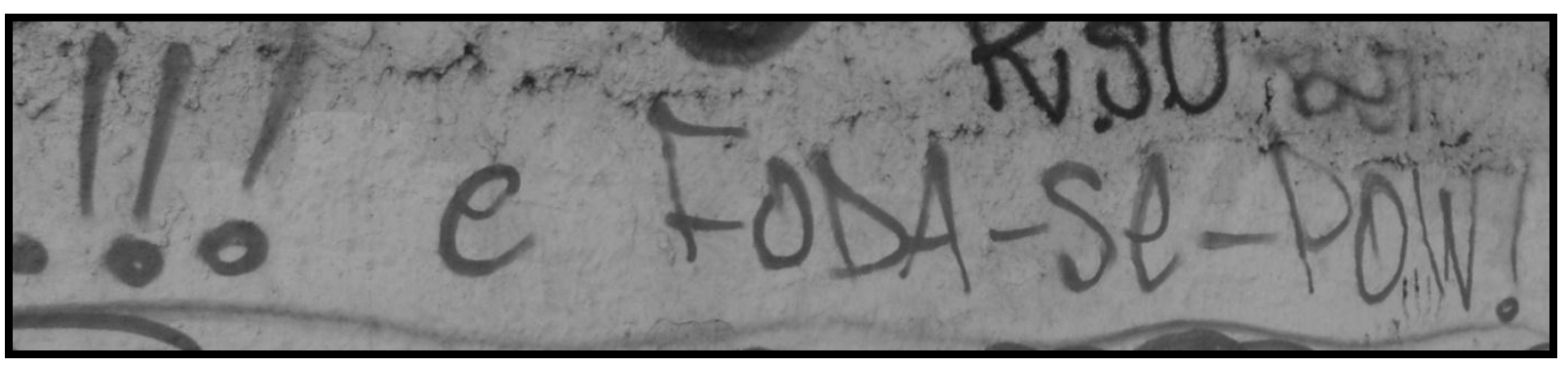

Figura 3: Muro da empresa Andrade Gutierrez, na Av. Constantino Ney em frente à Arena da Amazônia (foto de Rebeca Soares e Maison dos Anjos em 21 de abril de 2015)

Pode-se perceber que nessas três figuras há letras e palavras possíveis de decifrar e outras que não são de fácil entendimento, beirando, às vezes, a desenhos ou rabiscos, impedindo com que a mensagem proposta se torne codificada por quem está fora do grupo. "A pichação emprega poucas cores, muito texto, privilegiando as formas e as experimentações caligráficascriptográficas”. (SILVEIRA, 2012, pp. 18-19) 
Todavia, como nossa proposta são as que se podem ler, então, têm-se basicamente mensagens idênticas com caligrafias distintas no mesmo muro, relativamente próximas. Como o desenho das letras é diferente e as cores também, pode-se supor que são duas pessoas disputando o mesmo local, ou pessoas do mesmo grupo que se dirigem a um terceiro, compartilhando o mesmo espaço.

Ao levarmos em consideração a mensagem essa porra é tudo nosso!!! e Foda-se pow! ou essa porra é nossa!!! , tem-se como possibilidade de interpretação que a palavra essa por ser um pronome demonstrativo, pode se referir ao muro, as redondezas ou a algo que não está claro na mensagem por não estarmos inserido no contexto, contudo, é uma forma de aviso, de demarcação de território. Para Russi Duarte (2009, p. 3) “entender no ato da pichação a estética comunicativa provoca um tecido infinito de operações."

Esse tecido infinito nos deixa com um fator primordial: a ação de escrever ou deixar inscrito algo para que o maior número de pessoas possa ver. O muro não é o melhor suporte para se deixar uma marca. Geralmente muros são construídos para proteção, para demarcação de imóveis, para delimitar o público do privado, para diferenciar classes sociais, na tentativa de prevenir invasões e roubos por exemplo. Uma marca do capitalismo, da divisão de classes, da vida urbana. "É nos muros, nas pilastras, nas grades, no chão que o sujeito tenta se fazer ouvir, dar a ler esse resto não significantizado.” (MARIANI, 2014, p. 131)

Ao se escolher o desenho ou a frase que se queira deixar em detrimento de outro, ao escolher o muro e a avenida, eliminam-se outros lugares, outros bairros, outros conteúdos. Podese presumir que quanto mais visibilidade se deseja, mais se quer ser visto ou mais o conteúdo da mensagem pode importar aos citadinos que por ali passam. Ou ainda, que para o sujeito que escreve, isso é digno de ser lembrado, algo que não se pode esquecer, seja ele, seja para o outro.

\section{PROTESTOS}

Pichar também pode ser encarado como uma forma de demonstrar insatisfação, mas fazê-lo pode ser perigoso, seja pelo comportamento em si, de pichar, seja pelo conteúdo que se propõe. Hoje, com o advento da internet é possível criar blogs, marcar encontros e protestar sem se deslocar fisicamente, expondo-se. Todavia, a forma mais eficaz de se fazer isso ainda é se reunindo em praças, em frente de prefeituras, ou seja, deslocando-se. Um dos melhores exemplos é a famosa imagem da inscrição abaixo a ditadura, escrita num momento político delicado e muito perigoso, com protestos comandados por movimentos estudantis. Para Marques (2015, p. 
86) "a pichação é um sintoma de uma cidade praticada de outra forma, onde um viaduto não representa apenas um mecanismo para facilitar a fluidez."

Qualquer lugar público com visibilidade pode se tornar um papel em branco, pode ser suporte para a escrita ou marca de alguém, por mais que permanência não seja garantida. Utilizase então os lugares construídos nos centros urbanos, como viaduto, muros, postes e prédios com outra finalidade. "Estou propondo que toda pichação supõe a urbanização" (DUARTE, 2009, p. 4).

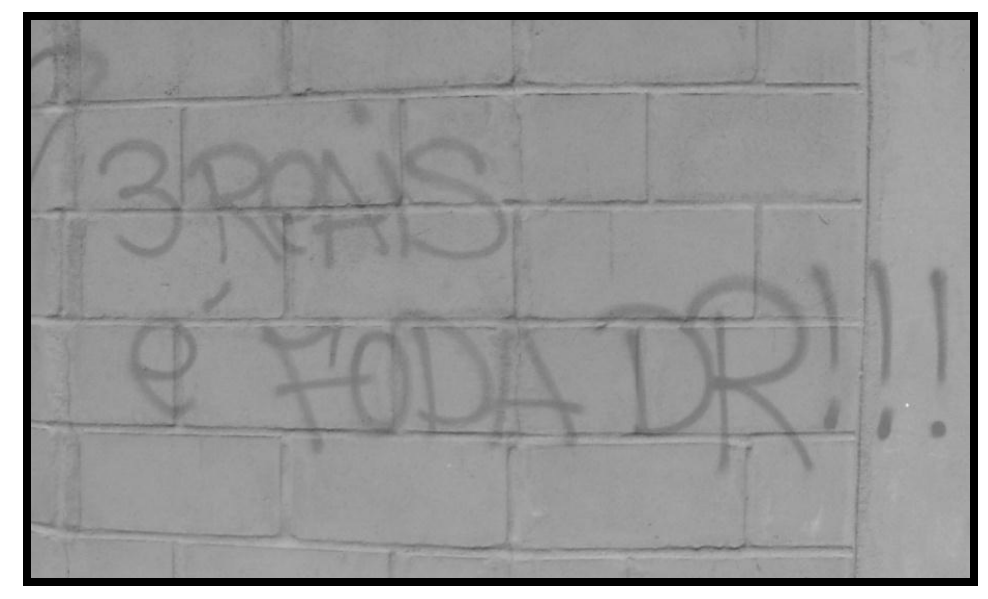

Fotografia 4: Muro de um condomínio fechado, Av. Constantino Nery, Chapada. (foto de Rebeca Soares e Maison dos Anjos em 21 de abril de 2015)

Nessa pichação 4, propõe-se a relação com o aumento da tarifa do transporte coletivo público, pois segundo o site da Câmara Municipal de Manaus, a passagem de transporte coletivo em Manaus aumentou de $\mathrm{R} \$ 2,75$ para $\mathrm{R} \$ 3,00$ dia 18 de janeiro de $2015^{3}$. Houve manifestações, protestos, mas pontuadas. A inscrição no muro permaneceu por muito mais tempo do que as vozes ao vento.

Outro fator a ressaltar é a cidade, é subjetiva não por si só, mas por ser reflexo de quem a constrói, a compõe e a modifica. Para Bentes (2012, p. 16), "não há representações que não sejam produzidas pelas práticas sociais contrárias e em confronto, pelas quais os indivíduos e os grupos dão sentido ao mundo em que vivem."

O autor dessa oração reconhece a divisão de funções numa sociedade, a divisão de profissões e classes sociais ao reclamar do preço da passagem ao doutor. Seja por reconhecer as

\footnotetext{
${ }^{3}$ http://www.cmm.am.gov.br/passagem-de-onibus-aumenta-para-r3-mas-prefeitura-nao-apresenta-melhorias-para-osistema-de-transporte-publico-defende-rosi-matos/. Pesquisado dia 11 de Setembro de 2015 às $19 \mathrm{~h}$.
} 
diferenças em que se encontram, seja por uma mera tradição de se dirigir a alguém que se diz superior, por doutor, ou até mesmo por ironia.

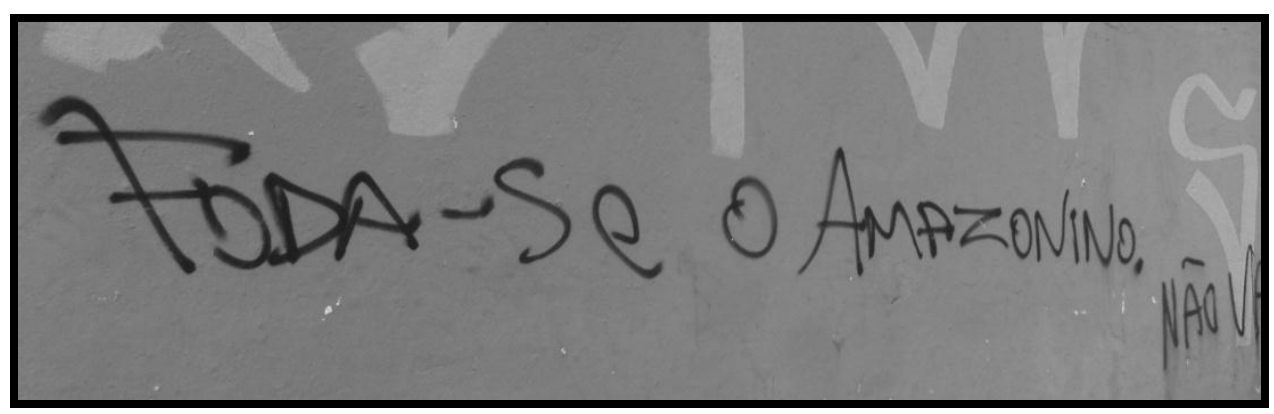

Figura 5: Muro do Clube Sírio Libanês. Av. Constantino Nery, Chapada (foto de Rebeca Soares e Maison dos Anjos em 21 de abril de 2015)

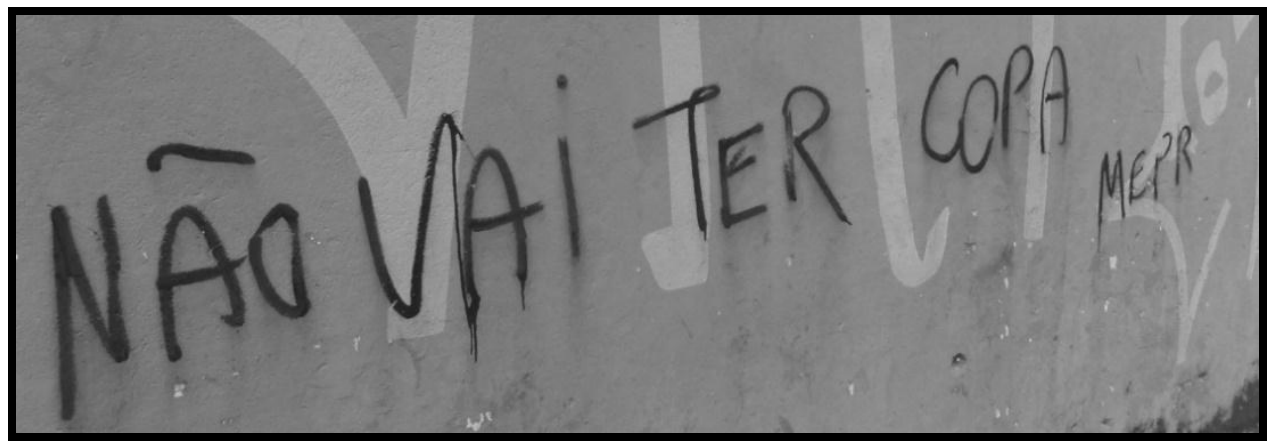

Figura 6: Muro do Clube Sírio Libanês. Av. Constantino Nery, Chapada (foto de Rebeca Soares e Maison dos Anjos em 21 de abril de 2015)

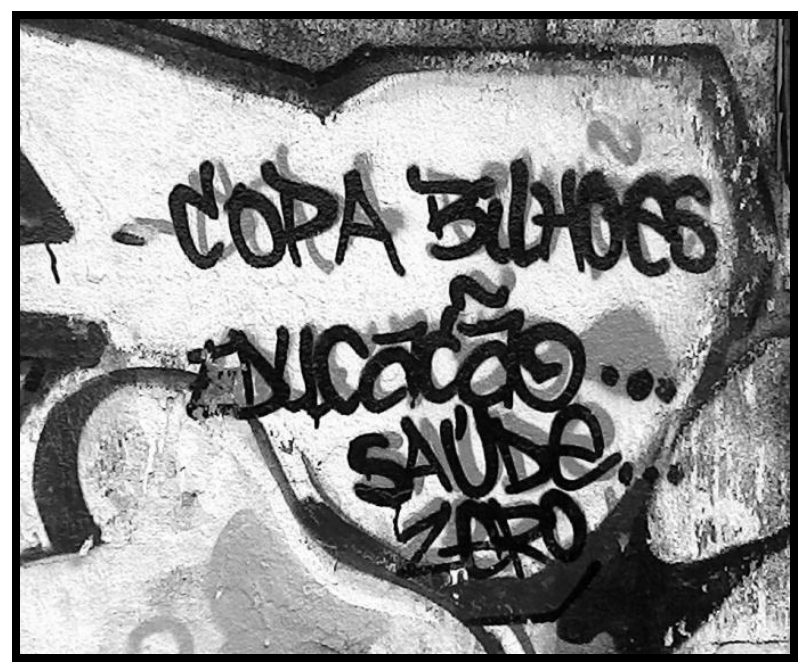

Figura 7: Muro na Av. Djalma Batista.

(foto de Rebeca Soares e Maison dos Anjos em 21 de abril de 2015)

Seguem-se os protestos, entretanto agora sobre a Copa do Mundo, que aconteceu no ano de 2014 e Manaus foi uma das sub-sedes. Segundo portal da transparência: Controladoria Geral 
da União, o investimento previsto para Manaus ${ }^{4}$ era 1.308.237.018 (um bilhão, 308 milhões e 18 centavos). Construção da Arena da Amazônia, melhorias em seus arredores, na mobilidade urbana e até a construção de um monotrilho geraram muita repercussão na capital amazonense. Com o passar dos meses, algumas das modificações não foram executadas, como o monotrilho e acidentes na construção da Arena. Ora, "as populações urbanas não são passivas; elas são capazes de intervir na cidade, transformando-a em seu proveito". (PINHEIRO, 2001, p. 22 apud BENTES, 2012, p. 38)

O Movimento Não vai ter copa foi de âmbito nacional, iniciando em São Paulo e deslocando-se para as demais cidades-sedes, com reivindicações de direitos como hospitais mais bem equipados, segurança pública, transportes públicos adequados, fossem na forma de passeatas, redes sociais, ou cartazes espalhados pela cidade. Assim como os manifestantes se expressaram por aqueles veículos, demonstrando sua insatisfação, os pichadores tomam como veículo os muros da cidade para, da mesma forma, protestarem e deixarem sua indignação registrada. No fim, os objetivos podem ser considerados semelhantes, o que muda é o meio utilizado, a diferença se firma no meio pelo qual a expressão da opinião chega até o outro.

É importante frisar que as últimas fotografias, as pichações se sobrepõem. Nas figura 5 e 6, percebe-se que a última pichação tenta anular a primeira, como se esta já tivesse cumprido seu papel de expressão, deixando que aquela tome seu lugar enquanto mensagem. Levando em consideração que o suporte utilizado, o muro, não é uma construção para tal prática, a conservação da inscrição e o valor dado a ela pode depender de inúmeros fatores, um deles é, por exemplo, a rivalidade dos que praticam esta atividade, sobrepondo-se, anulando-se, passando por cima de outro discurso, de outra inscrição, de outra pessoa.

Na figura 7, nota-se que a última pichação também se sobrepõe à primeira, mas diferente das figuras 5 e 6, não busca anular a primeira, utiliza o espaço presente dentro da primeira pichação para fazer o registro do protesto, fazendo com que assim, as duas mensagens possam ser percebidas e coexistir. "A identificação e apropriação espacial do urbano por indivíduos de uma localidade estão intimamente ligadas aos valores antropológicos e filosóficos, os quais determinam o nível de exultação e contentamento destes com o ambiente em que vivem." (FARIAS, 2010, p. 54)

Pode-se perceber nessas últimas imagens o contentamento negativo. A apropriação dos muros tem sido um dos meios pelos quais os indivíduos urbanos têm encontrado para serem

\footnotetext{
${ }^{4} \mathrm{http} / /$ www.portaltransparencia.gov.br/copa2014/empreendimentos/investimentos.seam? menu=3\&assunto=cidade . Pesquisado dia 11 de Setembro de 2015 às $19 \mathrm{~h}$.
} 
vistos. "E em se tratando de cidade, a relevância em rememorar está no significado atribuído pelo grupo ao lugar”. (FARIAS, 2010, p. 56)

\section{DISPUTA}

Não se nota nessas pichações a ideia de afronta ou marcas de territorialismo, que se apresentam quando um pichador picha sobre a marca de um outro pichador, diferentemente como se pode observar na fotografia 8 . Para tal situação, utilizaremos o conceito de profanação de Agambem (2007, p. 66), expondo que "profanar significa abrir a possibilidade de uma forma especial de negligência, que ignora a separação, ou melhor, faz dela um uso particular.”

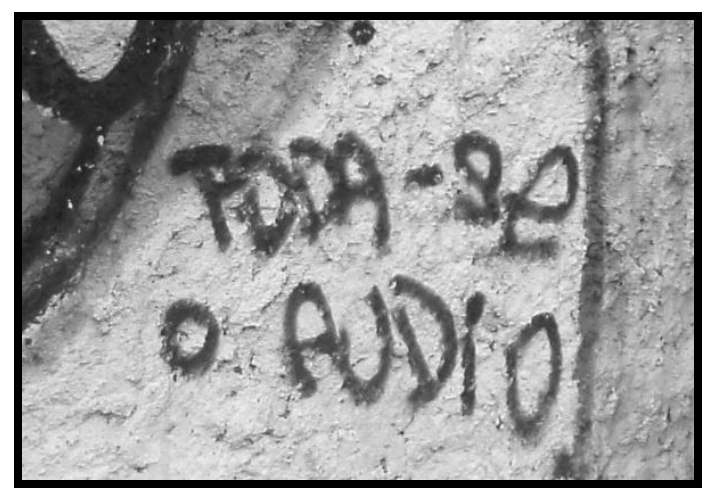

Figura 8: Muro na Av. Djalma Batista.

(foto de Rebeca Soares e Maison dos Anjos em 21 de abril de 2015)

Essa definição abarca, basicamente, a pichação, pois é uma possibilidade especial de negligência, com um fim, com um objetivo. Levando em consideração que o "urbano são espaços nos quais se vive em constante renovação, transformação" (DUARTE, 2009, p. 7), as manifestações ao longo da cidade são a prova mais incontestável disso. Um mesmo muro pode então, ser utilizado diversas vezes, permitindo que outras mensagens possam ser grafadas no mesmo espaço, sobrepondo-se, coexistindo.

Mediante o exposto, podemos considerar que "o pichador se apropria da cidade no momento em que grafa o seu nome ou apelido (tag) nos prédios, circula nos espaços centrais demarcando o seu território, e acima de tudo, tornando visível sua existência como usuário signatário da cidade." (MARQUES, 2015, p. 85) Isso se observa de forma explícita na fotografia a seguir, onde o pichador que se identifica como Áudio mostra ainda estar presente, apropriandose daquele espaço da cidade, ainda que haja outro pichador se utilizando do mesmo espaço, como é o caso do pichador 3R, que na fotografia aparece sua marca (tag) no canto direito, acima. 
Correlacionando a pichação 8 e 9, pode-se supor uma disputa por território, a luta pelo mesmo espaço. Tem-se então, duas possibilidades de perceber a pichação de modo prático. Primeira, há inscrições que podem coexistir, seja lado a lado, seja quando sobrepostas. Segunda, há manifestações escritas que não se sobrepoem, mas lutam por um espaço maior que o simples muro, um espaço para escrever, mais que um suporte específico.

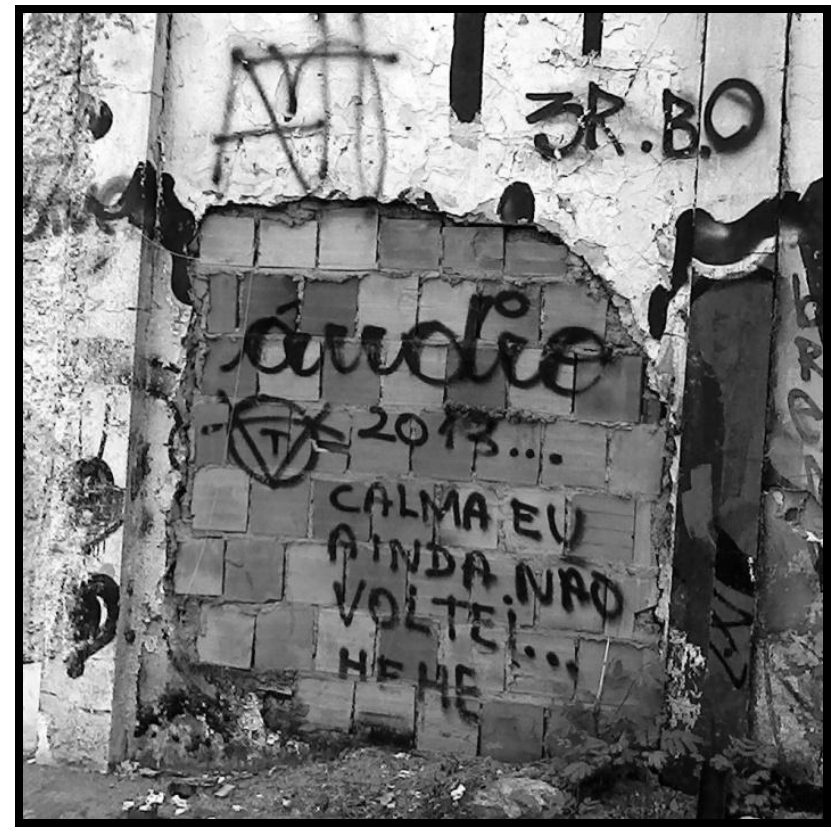

Figura 9: Muro na Av. Djalma Batista.

(foto de Rebeca Soares e Maison dos Anjos em 21 de abril de 2015)

Os pichadores parecem transparecer que sua forma de expressão é algo que deve ser percebido e valorizado, que deve ter um papel importante dentro da cidade, seja com a intenção de vandalizar, querendo deixar sua marca, ou simplesmente como autoafirmação perante a sociedade, mesmo que essa não consiga compreender qual a intenção destes. Para Pignatari (1995, p. 205), “a cidade é uma mensagem que nem todos entendem, mas que todos são obrigados a ler".

\section{VALORAR-SE}

Como último ponto de análise, pode-se perceber que algumas escritas são de autoafirmação ou de confirmação que a atividade realizada é de alguma valia. Como na inscrição abaixo Agente brinca mais não é brincadeira. Dito de outra forma, há outros que somente 
brincam, diferente dele, que assina como Chavez Tom, confirmando alguma seriedade, deixando uma tag. Por outro lado ainda, essa pichação pode ser também de uma música, chamada Bang, de Shawlin, que conta a história de uma vida noturna, passageira, vivida a base de entorpecente, de um eu que ora está alheio ao que está ao redor, ora sente uma espécie de dor existencial, de se encontrar em um caminho sem volta.

Mediante o que se pôs, na medida em que algo é escrito, seja num livro, seja em um muro, suas interpretações, suas leituras e entendimentos são compartilhados com o leitor, o que proporciona um leque de possibilidades de interpretação.

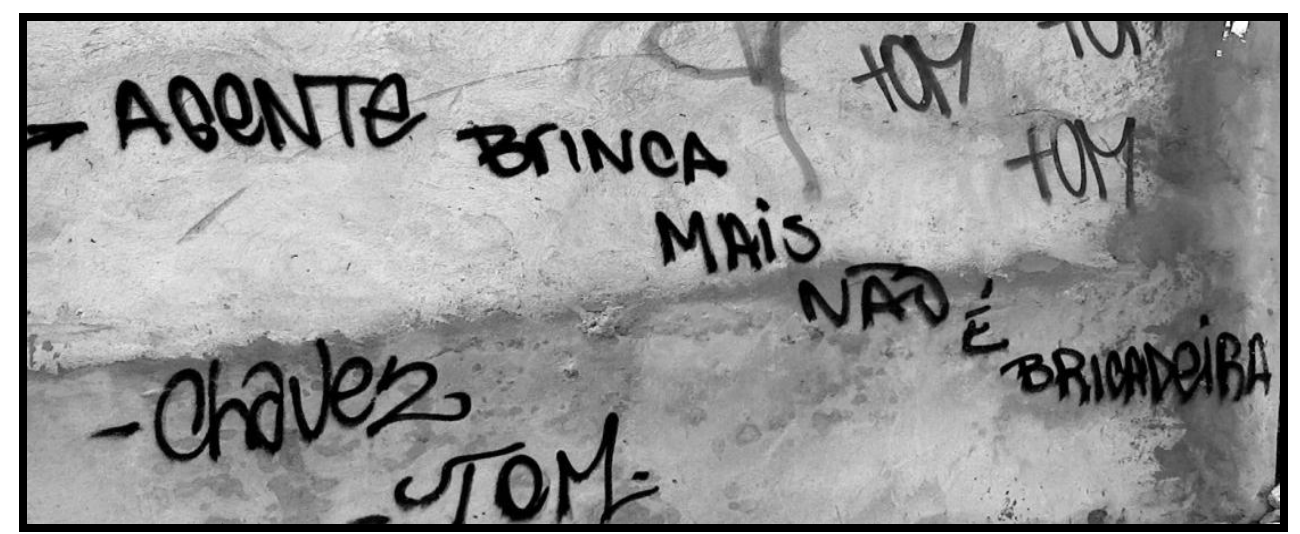

Figura 11: Muro na Av. Djalma Batista.

(foto de Rebeca Soares e Maison dos Anjos em 21 de abril de 2015)

Corroborando com a valoração de si, tem-se outra inscrição, no qual a confirmação de que seu comportamento é bom, é feito, muitas vezes, em contrapondo com outros, como a figura 10 Não sou o melhor mais me garanto. Admite-se que há outros, pichadores ou não, que são melhores, mas a eficiência é garantida. 


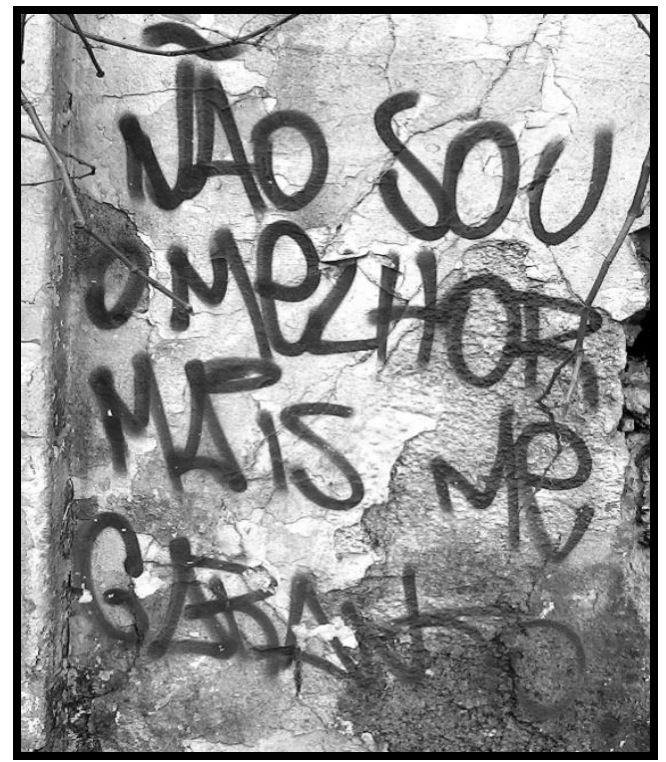

Figura 10: Muro na Av. Djalma Batista.

(foto de Rebeca Soares e Maison dos Anjos em 21 de abril de 2015)

\section{CONSIDERAÇÕES FINAIS}

Ao longo das pichações apresentadas, é visível que as frases, na maioria das vezes, não estão de acordo com a Normal culta, levamos em consideração assim, as marcas como gírias, nestes casos, por grupos, ou por classe social, sendo esta última de mais difícil comprovação.

Entretanto, esse não é o foco pretendido. É possível confirmar que o ato de arriscar-se para escrever uma mensagem, deixar uma tag é tão importante e até tão necessário quanto a mensagem que de pretende. Huzinga (1971, p. 4), citado por Duarte (2009, p. 10), expõe que no “jogo existe alguma coisa 'em jogo' que transcende as necessidades imediatas da vida e confere um sentido à ação"

Chega-se, então, a algumas considerações ao sentido da ação da pichação. Primeira delas é que nem todos os símbolos ou Tags são de livre compreensão a qualquer cidadão que se propõe a lê-las. O grupo, dos que picham, pode utilizar o muro como forma de comunicação interna. Em segundo lugar, há mensagens destinadas a pessoas foram do grupo - Dr., Áudio, Amazonino - ou ao indivíduo que faz parte da referida cidade, como um cidadão urbano.

Em terceiro lugar, as mensagens podem ser de cunho social e político, com a finalidade de protestar, seja pelo aumento do valor da passagem do transporte coletivo - regional - seja pelos investimentos destinados ao evento da Copa do mundo, considerado por eles, em demasia eventos nacionais. 
E por fim, mas que engloba todos os itens já mencionados, o desejo de ser ouvido, de expor que um grupo, que uma parcela da população tem algo a expor e a pichação foi o meio escolhido para tal. Um meio que desconsidera as leis que a cidade instaura para organização e seleção de comportamentos desejados. Poucos têm coragem, é pra poucos que tem estilo!

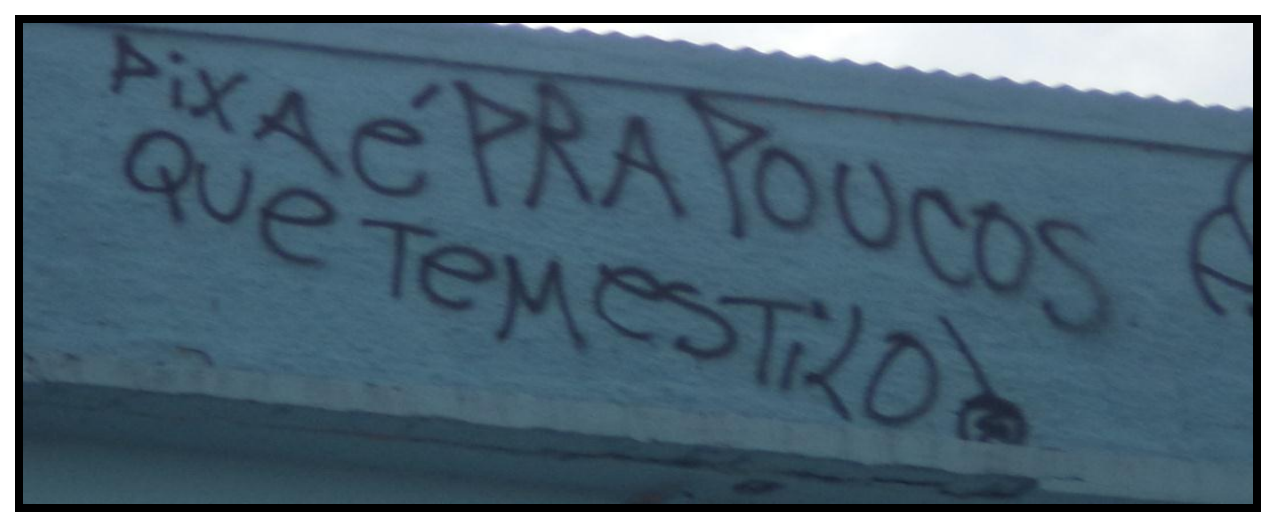

Figura 13: Anexo da igreja São Geraldo, na Av. Constantino Nery. (foto de Rebeca Soares e Maison dos Anjos em 21 de abril de 2015)

\section{REFERÊNCIAS}

AGAMBEM, Giorgio. Elogio da Profanação. In: Profanações. São Paulo: Boitempo Editorial, 2007.

BENTES, Dorinethe. Outras faces da história: Manaus: 1910-1940. Manaus: Reggo edições, 2012.

DUARTE, Pedro Russi. Estética comunicativa das pichações. In: XVIII Encontro da Compós, Belo Horizonte. Artigo ,18. 2009.

MARIANI, Bethania; MEDEIROS, Vanise. Discurso urbano e enigmas no Rio de Janeiro: pichações, grafites, decalques. Revista Rua | Campinas | Edição Especial - 20 anos | 2014.

MARQUES, Bruno Strohmeyer; COELHO, Ilanil. Grafias urbanas: o patrimônio profanado pela pichação. Profanações (ISSN - 2358-6125) Ano 2, n. 1, p. 75-89, jan./jun. 2015.

PIGNATARI, Décio. Letras, Artes, Mídia. São Paulo: Editora Globo, 1995.

SILVEIRA, Fabrício. Grafite Expandido. Porto Alegre: Modelo de Nuvem, 2012.

FARIAS, Soraia Aparecida Martins. Cidade-museu : expressões espaciais e o caráter cultural Dissertação (mestrado) - Universidade Federal de Minas Gerais, Escola de Arquitetura. 2010.

TAVARES, Andréa. Ficções urbanas: estratégias para a ocupação das cidades. ARS Ano 7, $N^{\circ} 16,1^{\circ}$ Seminario Internacional sobre Arte Público em Latinoamérica, promovido pelo Grupo 
de Estudios sobre Arte Público en Latinoamérica, Universidad de Buenos Aires, novembro de 2009.

Recebido em: 12/10/2018

Aprovado em: 05/11/2018

Publicado em: 10/12/2018 